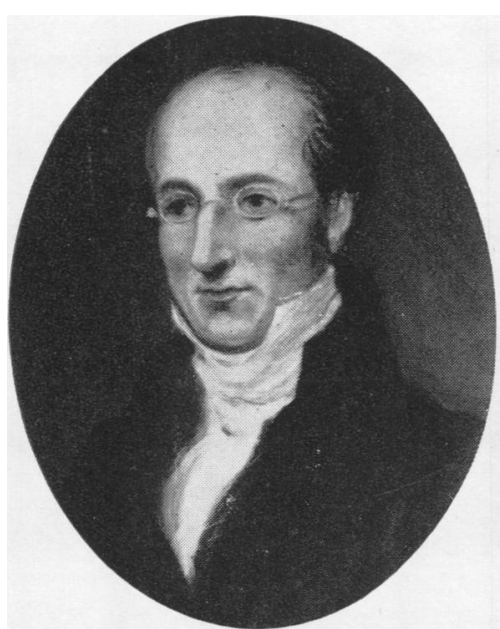

Charles Turner Thackrah (1795-1833)

From an original painting in the Medical Library of the University of Leeds

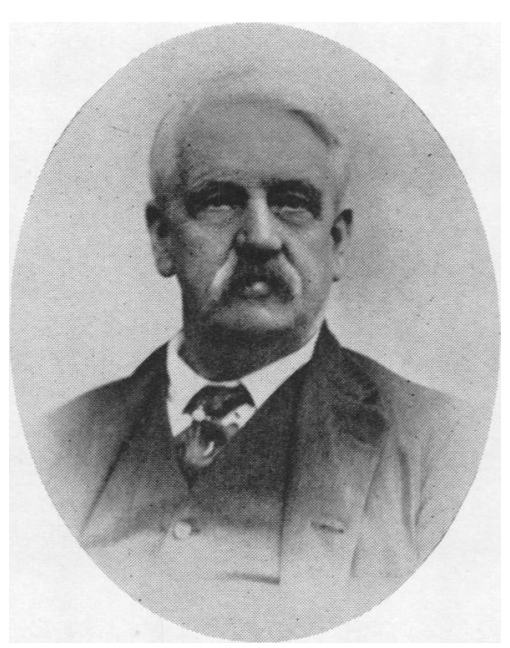

Sir Arthur Whitelegge (1852-1933 From an original photograph

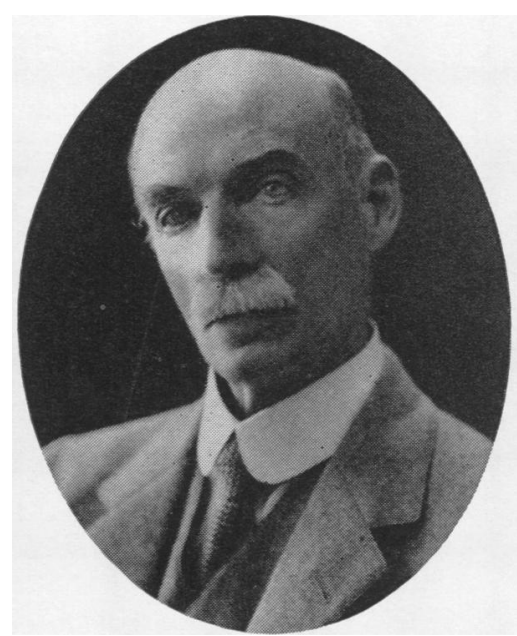

Sir Thomas Legge (1863-1932)

From an original photograph in the Wellcome Historical Medical Museum

\title{
SIXTY YEARS OF INDUSTRIAL MEDICINE IN GREAT BRITAIN
}

\author{
BY \\ ANDREW MEIKLEJOHN \\ From the Department of Industrial Health, University of Glasgow
}

On September 27, 1956, the Association of Industrial Medical Officers meets in London to celebrate its coming of age. The event is an appropriate occasion on which to recall briefly the progress of industrial medicine in Great Britain during the past 60 years.

\section{Historical}

Commencing with the Health and Morals of Apprentices Act, 1802, Parliament, through a succession of statutes, established its right to intervene in the regulation of employment in factories. Concurrently workmen won the right to combine in trade unions to safeguard their conditions of labour. As a result, over the century, hours of labour were abridged, the conditions of employment of women and children-the protected classes - were regulated, and education was extended among the working classes through schools and mechanics' institutes. By 1897, the year of Queen Victoria's Diamond Jubilee, Britain had become the leading industrial and commercial nation in the world. The machines, earlier regarded as the enemy of the manual worker, had resulted in great material wealth and prosperity, seemingly capable of limitless expansion. But over this glittering achievement and prospect there crept a dark increasing shadow: the factories were causing death and invalidism through accidents and disease. As a measure of alleviation workmen's compensation legislation was enacted, while Factory Acts were increasingly directed towards the promotion of safety, health, and welfare. Meanwhile legislation for non-factory workers, in the mines, in transport, in agriculture, and in shops and offices was trailing slowly in the rearguard of the Factory Acts.

\section{Sixty Years Back}

In March, 1896, Dr. Whitelegge (later Sir Arthur), County Medical Officer of Health of the West Riding of Yorkshire, was appointed Chief Inspector of Factories under the Home Office. He is the only medical man ever to occupy this position. Among his contemporaries his appointment was enthusiastically acclaimed for he had established a reputation not only as a great physician in preventive medicine but also as an outstanding administrator. Furthermore, in his daily work in the West Riding Whitelegge had walked in the steps of the master, Dr. Charles Turner Thackrah of Leeds. Two years 
later, in 1898, Dr. Legge (later Sir Thomas) was appointed to be the first Medical Inspector of Factories. As proved by immediate developments, which were ultimately to influence the progress of industrial medicine in Great Britain and throughout the world, the times were fortunate in these leaders. Sixty years on, we are proud to salute their memory and achievements.

\section{Advance through Legislation}

In the 60 years between 1896 and 1956 perhaps the greatest single contribution to the advance of industrial medicine was made through legislation, based on the researches and recommendations of such notable leaders as Oliver, Goadby, Legge, Cathcart, Vernon, Collis, and many others. The contribution of the Factory Department was outstanding and a fitting continuation of the pioneer work of Howell, Horner, Rickards, and Saunders, the original four inspectors of factories, who were appointed in 1833. It would be wrong, however, to think entirely in terms of Factory Acts and Mines Acts and associated Orders and Regulations. These were directed to safety, health, and welfare, but they were supplemented by Workmen's Compensation Acts (now Industrial Injuries) and the Disabled Persons (Employment) Act, 1944.

The first Workmen's Compensation Act was passed in 1897. It related solely to injury by accident. In 1906 the Act was extended to cover industrial diseases of which six were named. These were poisoning by lead, mercury, arsenic, phosphorus; and anthrax and ankylostomiasis. The Home Secretary was empowered to add to these scheduled diseases (now prescribed diseases) and this immediately led to pressure by the workers and their unions for the inclusion of other trade diseases. Thus it became necessary to establish tests whereby industrial diseases could be distinguished from diseases in general. The first series of tests was formulated by the Samuel Committee (Home Office, 1907) and the subject has since been reviewed by committees under the chairmanship of Holman Gregory (Departmental Committee on Workmen's Compensation, 1922), Rolleston (Home Office, 1933), Dale (Ministry of National Insurance, 1948), and Beney (Ministry of Pensions and National Insurance, 1955). The discussions have involved consideration of such problems as connotation of "disease", "specific to the employment in the individual patient", and "balance of probability" test. It has also been necessary to distinguish between disease by accident and disease by gradual process. Among the diverse diseases which have been dealt with are silicosis, Weil's disease, chronic poisoning by carbon monoxide, tuberculosis, Raynaud's phenomenon, and finally cadmium poisoning. Prescribed diseases at present number 41 , in addition to byssinosis and pneumoconiosis, which are covered by special legislation. Workmen's compensation, apart from Common Law liability, is now embraced in the National Insurance (Industrial Injuries) Act, 1946.

Despite the annual toll of death and accidents at work, it is remarkable that no constructive national effort for the well-being of disabled and handicapped persons was instituted until after World War I, when attention, or rather emotion, was excited by the return to civil life of thousands of men broken mentally and physically. The first attempt at a scheme for employment was the King's Roll of Disabled, but the charter of the disabled (the Disabled Persons (Employment) Act, 1944) was not achieved till 25 years later. While meantime the profession and the hospitals generally have assisted in promoting rehabilitation, special contributions have been made by the Royal Albert Docks Hospital, London, and the Birmingham Accident Hospital; by the rehabilitation workshops at Austin and Vauxhall Motors; by Remploy and by Roffey Park. For the patient a most valuable advance has been made in that the emphasis has been transferred from disability and incapacity for work to residual ability and capacity. Towards this Stewart (1939), and the techniques of job analysis associated with the work of Hanman (1951), have made a substantial contribution.

All this notwithstanding this specific industrial legislation must not be regarded in isolation, for the workers have shared with all in the advances which have resulted from public health legislation, education acts, and the comprehensive provisions for national health and welfare.

\section{Medical Services in Industry}

The statutory medical services represent the measures for enforcement of the Factories Acts and related Orders and Regulations. They are mainly the concern of the appointed factory doctors (originally the certifying surgeons) under the supervision of the medical inspectors of factories. The Factory Department has constantly endeavoured to extend and render more effective this medical supervision and since 1948 there have been important extensions, particularly in relation to the health examinations of young persons and supervision in premises not previously included in the definition of a factory. The pneumoconiosis panels undertake initial and periodical examinations in specified occupational groups in dusty industries, and since 
Reproduction of a watercolour of Newcastle-onTyne painted by Sir Thomas Legge

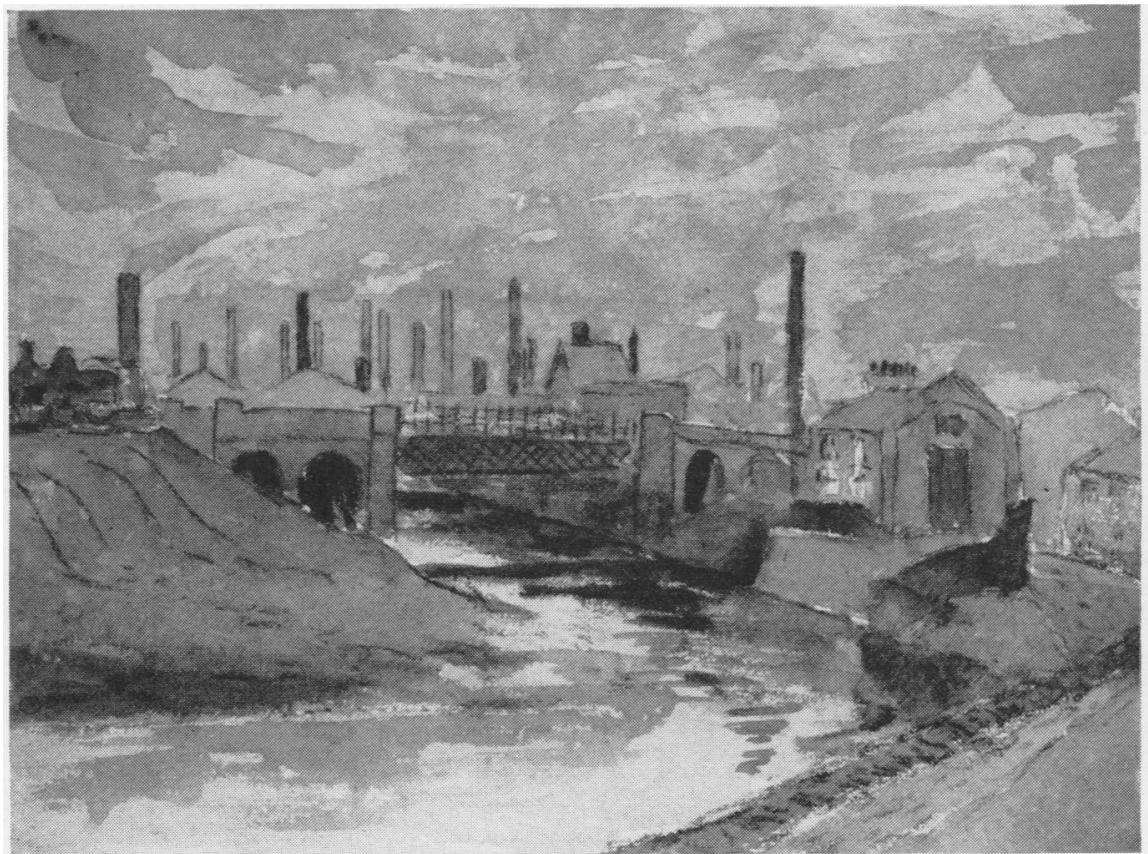

1952 a scheme has been developed for the examination of new entrants under the age of 21 years to the mining industry. These examinations are conducted by the medical officers of the National Coal Board.

The passing of workmen's compensation legislation, as previously recounted, led almost immediately to an increase of doctors in industry but almost entirely on a consultative basis. Their purpose was not primarily the care of the workmen nor the prevention of accidents and diseases but to help the employers to rebut claims for damages. Inevitably the workers and their trade unions came to regard the doctor as the employers' man and as such he excited hostility. There can be little doubt that this association of doctor and employer against the workman hindered the employment of the doctor for more beneficent services in industry. Even now the antagonism has not been entirely surmounted. However, in connexion with welfare services a few firms did succeed in introducing full-time doctors into their organizations. But as has so often happened in so many fields of human endeavour war has provided the necessary stimulus to advance. Thus the first world war focused attention on such problems as industrial fatigue, nutrition, T.N.T. poisoning, and the employment of women. These problems led to the establishment in 1915 of the Health of Munitions Workers Committee and in 1918 of the Industrial Fatigue (now Health) Research Board (Wilson, 1921, 1922). This was the beginning of the modern development of medicine in industry. Throughout the war there was an increase in medical services in industry, particularly in ordnance factories, but their employment soon declined with the coming of peace. However, certain progressive managements, especially in the chemical and engineering industries, had realized the potential advantages of medical supervision within the factory, and so a new group of doctors, if not a new branch of medicine, emerged.

\section{The Association of Industrial Medical Officers}

By 1935 the number of doctors employed in industry had so increased that a few leaders and their associates, chief among them Professor W. W. Jameson (later Sir Wilson) of the London School of Hygiene, Dr. Howard Mummery, and Dr. Donald Stewart decided that the time had arrived for the formation of a society of doctors employed full-time in industry. This was the origin of the Association of Industrial Medical Officers, which held its first meeting in the London School of Hygiene on September 27 and 28, 1935. Altogether 18 members, of a total of 35, attended. Dr. Howard Mummery was elected chairman. Dr. Leonard Lockhart opened a discussion on the future development of industrial medicine, at the conclusion of which it was agreed that at the next meeting Dr. T. Garland should introduce the topic of the relationship of the industrial medical officer to the general 


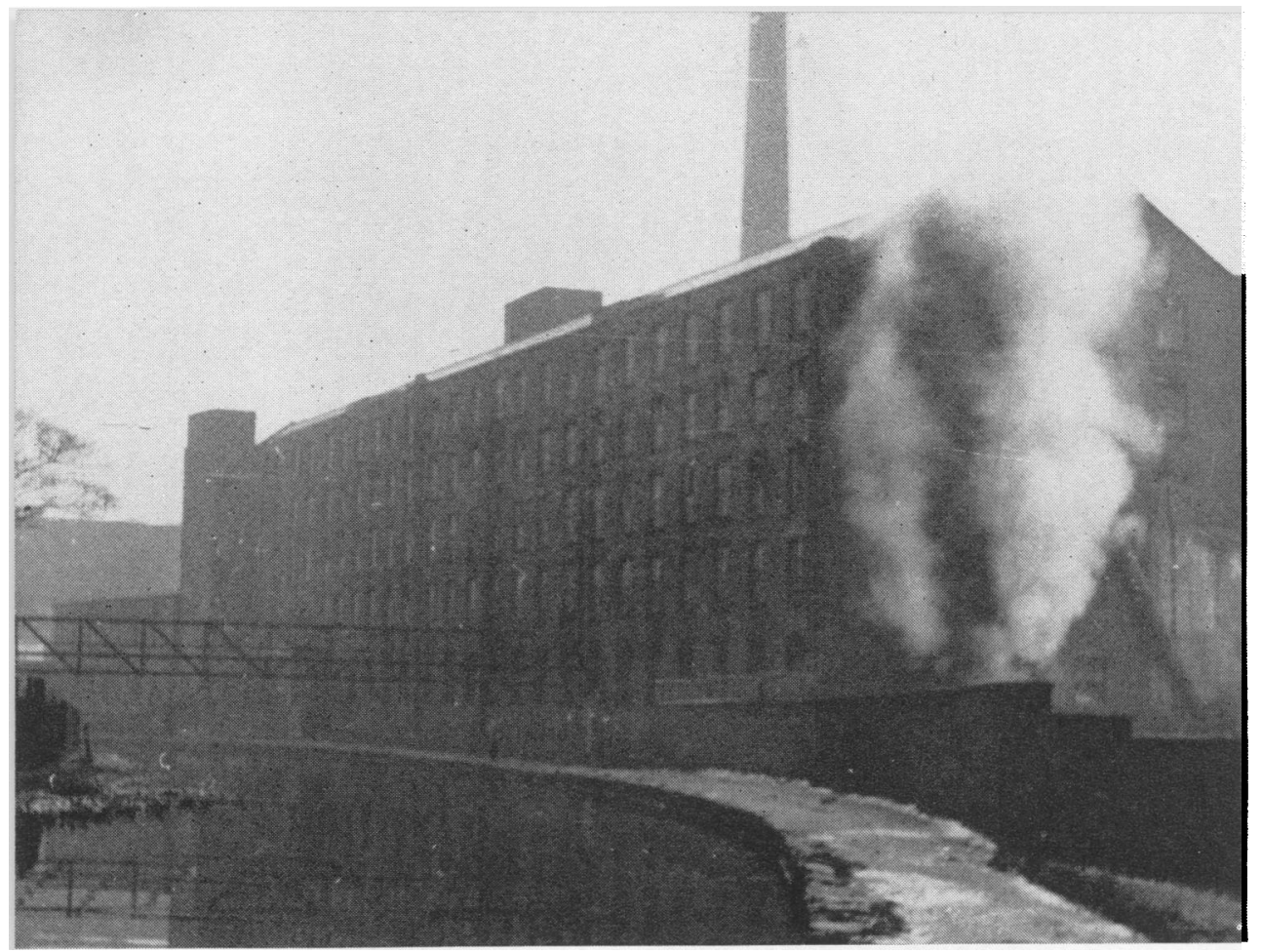

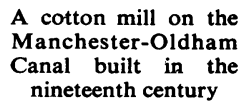

[By courtesy of Bryan Harvey practitioner. Membership of the Association steadily mounted as the number of doctors in industry increased. The increase of medical services in industry was greatly accelerated and advanced by the Second World War, especially after the fall of Dunkirk. Ernest Bevin, Minister of Labour and National Service, was the power behind this deyelopment and was ably supported by members of the Association, among whom we recall with admiration Sir David Munro, Dr. J. C. Bridge, and Dr. A. J. Amor. These were the leaders, but scores of others followed the unspectacular routine of keeping men and women-our civilian army-fit to endure the toil of long hours in the black-out and often under almost unremitting attack from the air. The shelters were there, but the workmen stuck to their benches.

Meanwhile, membership of the Association was extended to include part-time medical officers. At present the total membership is approximately 800 of whom some 400 are full-time. Alongside this development there has been an even greater increase in the number of nurses employed in industry, of whom 3,000 are State registered, including 900 who hold the certificate in industrial nursing.

In the constitution of the nationalized industries, it was recommended that the organization should include medical services. Thus the National Coal Board has established a full-time medical service directed by a chief medical officer assisted by 65 doctors, 300 nurses, and 20,000 first-aid men for the 700,000 men employed in coal-mines throughout Britain.
In 1948 the Ministry of Labour and National Service enquired into the extent, distribution, and content of medical services in factories. The results revealed that there existed a fairly extensive but patchy and uncoordinated occupational health service at the larger factories, but that there was little provision for small factories of which there are almost 203,000 ( $80 \%$ of total factories) which each employ less than 26 workers. Furthermore, employments outside factories-agriculture, transport, shops, and offices-were scarcely touched.

In factories where health services have been developed the scope and practice has extended considerably over the years. Compensation cases nowadays are usually referred to outside consultants and specialists, while the members of the health team devote themselves to general health and accident care, selection and placement of workers based on initial and periodical examinations, and rehabilitation. In addition these activities may be supplemented by physiotherapy, chiropody, dental and ophthalmic services, together with radiological, electrocardiographic, and laboratory facilities. This does not signify any attempt to replace or encroach on the sphere of the general practitioner or the clinic services of the hospitals, but is simply an endeavour to provide such facilities for accurate diagnosis and efficient immediate treatment as may enable the workman to continue on the job. In consultation with the workman's own doctor continued treatment may be provided at work. Basically the purpose is prevention of accidents and 


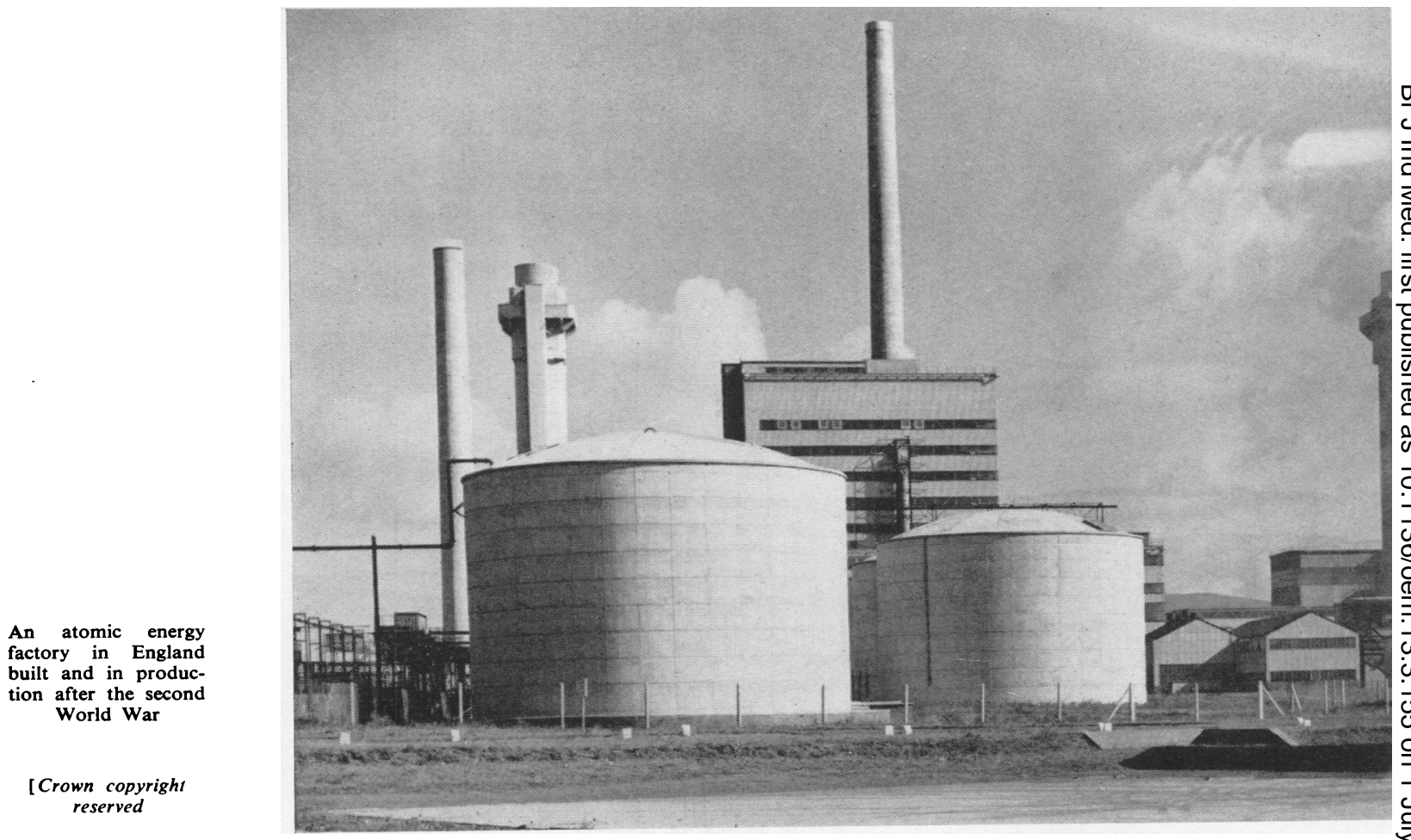

disease while alleviating the proximate and remote adverse effects of injury or disease.

\section{Industrial Toxicology}

At the turn of the century industrial toxicology was comparatively simple and was concentrated on poisoning by lead, phosphorus, mercury, and arsenic, all in inorganic form. A change, however, was in progress, whereby the organic chemist was placing an ever-increasing number of compounds at the disposal of a wide variety of industries. Interest was in their industrial and commercial value rather than in their toxic effects on workmen. World War I dramatically revealed their first assault in the form of T.N.T. poisoning among munition workers. This ultimately focused attention on the deleterious effects of organic chemicals on the liver and blood-forming organs. The attack increased and intensified through the use of aromatic and aliphatic hydrocarbons; and organic lead, mercury, and phosphorus, particularly with reference to insecticides and pesticides. To these in turn were added the hazards of ionizing radiations and poisoning by rare metals including beryllium, vanadium, selenium, and cadmium. And all the while an old enemy of the workman, silicosis, advanced; asbestosis was added and pneumoconiosis of coalworkers, distinguished as a separate pathological entity, brought disaster to the coalfields, particularly in South Wales. Industrial dermatitis increased and in the case of pitch and tar was associated with epitheliomatous ulceration. The results, however, were not all adverse for many of these risks were in due course effectively prevented or controlled. Lead poisoning in pottery manufacture and in the production of electric accumulators was successfully combated; silicosis in metal grinders, sand-blasters, and certain china workers was prevented: the risks of ionizing radiations and beryllium were controlled. All this was achieved by team work of scientists, doctors, and engineers and made effective through legislation, which, however, sometimes needed the prop and pioneer efforts of voluntary medical services as exemplified by Lane's work in the lead accumulator industry (Lane, 1949) and Jenkins' work in the gas industry (Jenkins, 1948).

\section{Research}

Research nowadays is regarded as an important measure of the vitality of a subject and its disciples. The record here both in fundamental and field studies is impressive, especially as in many instances it has been possible to translate the results into practical measures of prevention and control. As already remarked, the opening years of the century were dominated by the study of phosphorus poisoning, lead poisoning, and anthrax, in all of which Oliver and Legge played leading parts (Legge and Goadby, 1912; Oliver, 1908). Haldane (1904), Collis (1915), and Middleton (1936) instituted enquiries into dust diseases of the lungs, which led to the formation of the Industrial Pulmonary Diseases Committee of the Medical Research Council. Notable fundamental work on the aetiology and 
pathology of dust diseases of the lungs was carried out by Kettle (1926), Belt and Ferris (1942), King (1945), Matthew Stewart (1933), Gloyne (1930, 1932), Gough (1947), and Gough and Wentworth (1949). Among field studies the investigations of Merewether (1933) on asbestosis; of Sutherland and Bryson (1929) and Sutherland, Bryson, and Keating (1930) on silicosis; of Doig and McLaughlin (1936, 1948) on siderosis; of Hart and Aslett (1942) and Fletcher (1948) and his colleagues of the Pneumoconiosis Research Unit at Cardiff into pneumoconiosis of coalworkers. All these contributions have gained international recognition.

During World War I the Health of Munition Workers' Committee sponsored important enquiries into the nutrition of manual workers and into the physiology and psychology of work, associated respectively with the names of Cathcart (1928) and Vernon (1921). The studies of T.N.T. poisoning stimulated research in the field of industrial toxicology. In 1923 Dr. Alexander Scott, a general practitioner at Broxburn, published his classic work on skin cancer in paraffin workers, while Henry (1946), beginning with mule-spinners' cancer, instituted his life-long studies of occupational cancer. Noteworthy in the last 20 years are Lane's contribution to lead poisoning, Goldblatt (1947), Goldblatt, Farquharson, Bennett, and Askey (1954) and Case, Hosker, McDonald, and Pearson (1954) on bladder cancer, Hunter (1955) and his team on the organic insecticides, Williams (1952), and Loutit (1952) on ionizing radiations, and Schilling (1956) on byssinosis. In the more general field of toxicology the Medical Research Council's Toxicology Unit directed by Barnes (1953) has made a noteworthy contribution.

More recent studies include the toxic effects of rare metals, beryllium, vanadium, and cadmium; dermatitis in the manufacture and use of plastics; and Raynaud's phenomenon. All these mainly involve physical injury but it must be recorded that some of the most brilliant research has been into the mental effects of work and ageing. Vernon (1921) and Culpin and May Smith (1930) were the pioneers but the contributions of Sir Frederic Bartlett (1951) and his team at Cambridge have been pre-eminent.

In the more general field there have been numerous studies of sickness and absenteeism and of morbidity and mortality in particular occupational groups. Notable among these are Morris's investigations into coronary disease (Morris, Heady, Raffle, Roberts, and Parks, 1953) and those of Stewart and Hughes $(1949,1951)$ on tuberculosis. Occupational hygiene too has been ably advanced through the work of Dr. Thomas Bedford (1948) and this aspect of industrial health is now promoted through the British Occupational Hygiene Society which was founded in 1953. The Ergonomics Research Society is concerned with the investigation of human factors in work.

Industrial Health and Medical Teaching

Medical teaching on the influence of occupation on health and employment has generally been the affair of clinical teachers and so depended on the interest and knowledge of the individual teacher. All too often in such circumstances the subject received scant reference. Dr. Donald Hunter's unit at the London Hospital was a signal exception. Legge, according to Henry, advocated the need for better education in industrial medicine as part of the curriculum in medical schools, and he accepted lectureships on the subject at King's College, London, from 1920 to 1924 and at University College, London, from 1922 to 1929 and at Manchester University from 1920 until his death in 1932. I was one of his students at Manchester and can still recall the tall immaculate figure and the bright-coloured bow-tie just a trifle askew. He always entered the lecture-room-a modern Moses -carrying two immense folders which seemed to contain the whole corpus of English industrial law. His presentation was quiet and ever unpretentious but the student could not fail to realize the extent and intensity of his experience. As he walked before the benches, for he never used the rostrum, one felt that he was pacing the factory or foundry floor exchanging experiences with the workmen. Our notebooks pushed aside, we moved with him from factory to factory throughout Great Britain and all over Europe, studying the individual processes. But the mechanical side, albeit important, was incidental; our concern must be with skilled and busy craftsmen exposed to myriad risks. These risks constituted the challenge; they must be prevented and the responsibility in the matter devolved almost entirely on the employer. And all the while he excited in us something of the beauty of craftsmanship: of Chinese porcelain and mediaeval stained glass. By any standard, professional skill, scholarship, social purpose and, above all, sympathy and integrity, Legge was a great physician. Is it too much to hope that some day the London School of Hygiene may find a place on its façade to carve his name among the great ones already memorialized there ?

In 1934 the University of Birmingham realized the need for more specialized instruction than that provided by the clinical departments. A readership was established and Dr. Howard Collier became the first and, as it proved, the only holder of the appointment. As a general practitioner and 
certifying surgeon of mature experience he had sound qualifications for the post. However, he received little academic support and even less financial backing from industry. So after a very brief existence the department ceased, leaving one memorial, a textbook on occupational medicine with special reference to the psychological aspects.

The next venture came in 1945 when the Nuffield Foundation offered substantial funds to the universities of Manchester, Durham, and Glasgow to enable them to establish departments of industrial health. Manchester and Durham founded professorships and Glasgow a lectureship in the department of Public Health and Social Medicine. Edinburgh University from its own resources established a lectureship, while other medical schools introduced lectures on industrial health into the courses of Public Health and Social Medicine for undergraduates and postgraduates. A further step was taken by the institution of the Diploma in Industrial Health (D.I.H.) by the Society of Apothecaries, who were followed by the Conjoint Board for England and Wales, the Royal Faculty of Physicians and Surgeons of Glasgow, and the University of Edinburgh. The qualifying course occupied a full academic year. For a variety of reasons the necessary number of students did not materialize and so after a few years Edinburgh discontinued both the lectureship and the diploma. The University of Manchester has now intimated its intention to discontinue its department in its present form. There is now no full-time course save at the London School of Hygiene where the D.I.H. is combined with the D.P.H. on an elective basis. A part-time course is available at the Royal Institute of Public Health and Hygiene in London. Reviewing the work of its first 10 years the Nuffield Foundation indicated that the study of industrial health was among the less successful of its ventures. These facts, however, should not be interpreted as total failure, for, in fact, these departments have not been without success. This is proved by their contributions to research, to the training of doctors and nurses, and by their contributions to medical literature. There can be no dispute that industrial medicine has come to stay and signs, as exemplified by the setting up in 1955 of the Industrial Health Advisory Committee under the personal chairmanship of the Minister of Labour and National Service, proclaim advance. Among its advocates are the Royal College of Physicians of London (1945); the British Medical Association (1941); the Medical Practitioners Union; the Trade Union Congress; the Gowers (Home Office, 1949) and Dale (Industrial Health Services, 1951) committees. The universities must not abandon leadership in this field. Their need is to re-examine the problem and to devise means to promote the development of medicine in industry. The issue is no less than where do the universities stand in the future development of preventive medicine; in the conservation and promotion of health as opposed to the arrest and cure of disease ?

\section{The Literature}

One measure of the vitality of a subject is the extent and quality of its literature. The first textbook of the period under review was "Dangerous Trades" by Sir Thomas Oliver, which was published in 1902. "Industrial Maladies", based on experiences at the Factory Department, by Sir Thomas Legge appeared posthumously in 1934. Others followed, but recently two outstanding books have been published: "Industrial Medicine and Hygiene " ( 3 vols.) edited by Merewether (1954) and "The Diseases of Occupations" by Hunter (1955). These have greatly advanced the prestige of British occupational medicine.

Among periodicals the British Journal of Industrial Medicine founded in 1944 is highly regarded throughout the world. Other periodicals serving specialized groups comprise the Journal for Industrial Nurses, the Transactions of the Association of Industrial Medical Officers, Industrial Welfare, and the Industrial Law Review. Finally it is of interest to note the increasing number of articles and lectures on occupational medicine subjects in the general medical press and at conferences.

\section{Conclusion}

Early this year Sir Wilfrid Garrett, formerly H.M. Chief Inspector of Factories, following a visit to the Potteries, wrote: "The potters' shops (you will not believe it) are clean ". That simple comment may signify more for the future safety, health and welfare of the industrial worker and his dependants than concurrent advances in surgery and medicine. Final achievement will not come until, as stated by Merewether, " industrial hygiene (health) is not the pursuit of the few, but the practice of the multitude". And therein lies the responsibility of the universities which train doctors, scientists, and engineers.

\section{REFERENCES}

Barnes, J. M. (1953). Toxic Hazards of Certain Pesticides to Man. World Health Organization Monograph Series No. 16.

Bartlett, F. (1951). British Journal of Industrial Medicine, 8, 209.

Bartlett, F. (1951). British Journal of Industrial Medicine, 8, 209.
Bedford, T. (1948). Basic Principles of Ventilation and Heating. Bedford, T. (1948). Basic Principles of Ventilation and Heating. Lewis, London.

Belt, T. H., and Ferris, A. A. (1942). Spec. Rep. Ser. med. Res. Coun. (Lond.), No. 243.

British Medical Association (1941). Report of Committee on Industrial Health in Factories. London.

Case, R. A. M., Hosker, M. E., McDonald, D. B., and Pearson, J. T. (1954). British Journal of Industrial Medicine, 11, 75.

Cathcart, E. P. (1928). The Human Factor in Industry. Oxford University Press, London. 
Collis, E. L. (1915). Publ. Hlth (Lond.), 28, 252, 292; 29, $11,37$.

Culpin, M., and Smith, M. (1930). Rep. industr. Hlth Res. Board (Lond.), No. 61.

Departmental Committee on Workmen's Compensation (1922). Report by the Departmental Committee appointed to inquire into the System of Compensation for Injuries to Workmen. Cma the 816.
in

Doig, A. T. and McLaughlin, A. I. G. (1936). Lancet, 1, 771.

Flet, - (1948). Ibid., 1, 789.

Fletcher, C. M. (1948). Brit. med. J. 1, 1015, 1065.

Gloyne, S. R. (1930). Tubercle (Lond.), 11, 151.

-(1932). Lancet, 1, 1351.

Goldblatt, M. W. (1947). Brit. med. Bull., 4, 405.

-, Farquharson, M. E., Bennett, G., and Askew, B. M. (1954). British Journal of Industrial Medicine, 12, 1.

Gough, J. (1947). Occup. Med., 4, 86

and Wentworth, J. E. (1949). In Proc. 9th int. Congr. industr. Med., London, 1948, p. 66i. Wright, Bristol.

Haldane, J.' S. (1904). Report on the Health of Cornish Miners. H.M.S.O., London, Cd. 2091.

Hanman, B. (1951). Physical Capacities and Job Placement. Nordisk Rotogravyr, Stockholm.

Hart, P. D'A., and Aslett, E. A. (1942). Spec. Rep. Ser. med. Res. Coun. (Lond.), No. 243

Henry, S. A. (1946). Cancer of the Scrotum in Relation to Occupation. Oxford University Press, London.

Home Office (1907). Report of the Departmental Committee on Compensation for Industrial Diseases. H.M.S.O., London, Cd. 3495.

- Cd (1933). Second Report by the Departmental Committee appointed to Inquire and Report as to certain proposed appointed to Inquire and Report as to certain proposed extensions of the Schedule of Industrial Diseases to which
Section 43 of the Workmen's Compensation Act, 1925, applies. H.M.S.O., London.

-, (1949). Health, Welfare and Safety in Non-Industrial Employment (1949). H.M.S.O., London, Cmd. 7664.

Hunter, D. (1955). The Diseases of Occupations. English Universities Press, London.

Industrial Health Services Committee (1951). Report of a Committee of Enquiry on Industrial Health Services. H.M.S.O., London, Cmd. 8170.

Jenkins, W. D. (1948). Dermatoses Among Gas and Tar Workers. Wright, Bristol.
Kettle, E. H. (1926). J. industr. Hgy., 8, 491.

King, E. J. (1945). Spec. Rep. Ser. med. Res. Coun. (Lond.), No. 250. Lane, R. E. (1949). British Journal of Industrial Medicine, 6, 125. Legge, T. (1934). Industrial Maladies. Oxford University Press, London. and Goadby, K. W. (1912). Lead Poisoning and Lead Absorp-

tion. Arnold, London.
Loutit, F. J. (1952). Trans. Ass. industr. med. Off., 1, 185.

Merewether E R A (1933) Assubercle (Lond), 15, 69, 109 . (1954). Industrial Medicine and Hygiene (3 Vols.). Butterworth, London.

Middleton, E. L. (1936). Lancet, 2, 59.

Ministry of Pensions and National Insurance (1955). Report of the Departmental Committee Appointed to Review the Diseases Provisions of the National Insurance (Industrial Injuries) Act. H.M.S.O., London, Cmd. 9548.

Ministry of National Insurance (1948). Report of the Departmental Committee on Industrial Diseases. H.M.S.O., London, Cmd. 7557.

Morris, J. N., Heady, J. A., Raffle, P. A. B., Roberts, C. G., and Parks, J. W. (1953). Lancet, 2, 1053,'1111.

Oliver, T. (1902). Dangerous Trades. Murray, London.

(1908). Diseases of Occupation. Methuen, London

Royal College of Physicians of London (1945). (Social and Preventive Medicine Committee.) Second Interim Report on Industrial Medicine.

Schilling, R. S. F. (1956). In the press.

Scott, A. (1923). Eighth Scientific Report, Imperial Cancer Research Fund, p. 85.

Stewart, A., and Hughes, J. P. W. (1949). Brit. med. J., 1, 926.

(1951). Ibid., 1, 902.

Stewart, D (1939) Brit med J., 1, 963, 1019

Stewart, M. J. (1933). Liverpool med. clin. J., 41, 142.

Sutherland, C. L., and Bryson, S. (1929). Report on the Occurrence of Silicosis Among Sandstone Workers. H.M.S.O., London , and Keating, N. (1930). Report on the Occurrence of Silicosis Among Granite Workers. H.M.S.O., London.

Vernon, H. M. (1921). Industrial Fatigue and Efficiency. Routledge, London.

Williams, G. K. (1952). Trans. Ass. industr. med. Off., 1, 182.

Wilson, D. R. (1921). Welfare Work, 2, 185.

(1922). Ibid., 3, 3. 